\title{
Teleconnections of the tropical Atlantic and Pacific Oceans in a CMIP5 model ensemble
}

\author{
Irena Ott $\cdot$ Karin Romberg $\cdot$ Jucundus Jacobeit
}

\begin{abstract}
This study investigates the teleconnections between the tropical Atlantic and Pacific Oceans in 15 state-of-the-art fully coupled general circulation models and Earth system models without external SST forcing. In contrast to other studies, the teleconnection is considered in both directions-from the Pacific to the Atlantic and from the Atlantic to the Pacific. The model ensemble is generally able to simulate the propagation of atmospheric and oceanic signals to the adjacent ocean basin, generated by warm sea surface temperature (SST) anomalies in the tropical eastern oceans with Atlantic summer events lagging or leading Pacific boreal winter events. This is investigated by means of time-lagged composite analyses of different atmospheric parameters, including sea level pressure, wind, stream function, velocity potential, vertical air movement and divergent wind at several levels. However, the modelled inter-basin teleconnection and its correct frequency of occurrence depend on the strong warm SST biases in the Atlantic Benguela upwelling region and in the Pacific Ocean.
\end{abstract}

Keywords Teleconnection - Tropical Pacific - Tropical Atlantic $\cdot$ CMIP5 $\cdot$ Model ensemble

\section{Introduction}

The El Niño-Southern oscillation (ENSO) in the Pacific Ocean is the most prominent coupled ocean-atmosphere variability mode in the equatorial tropics. Warm and cold

I. Ott $(\bowtie) \cdot$ K. Romberg $\cdot$ J. Jacobeit

Institute of Geography, University of Augsburg, Alter Postweg

118, Augsburg, Germany

e-mail: irena.ott@geo.uni-augsburg.de sea surface temperature (SST) anomalies (El Niño and La Niña, respectively) in the central and eastern Pacific and air pressure oscillations between the western and eastern Pacific characterize the ENSO mode of variability. The oceanic counterpart in the Atlantic Ocean is called Atlantic zonal mode or Atlantic Niño/Niña, but its occurrence is less frequent and less intense (Florenchie et al. 2004). Warm water anomalies cause severe floods on the continental west coasts and harm marine ecosystems and fish populations in both oceans. Hence, many studies have investigated the cause and effect of anomalous SST conditions for decades (Zebiak 1993; Carton and Huang 1994). The influence of the Pacific ENSO system on the adjacent oceans was subject to several research studies in the last few years. A strong impact on the Indian Ocean and its monsoon system (at least until the 1970s) seems to be assured (Webster and Palmer 1997; Klein et al. 1999; Hong et al. 2010), whereas the impact of the Pacific Ocean on the Atlantic Ocean is discussed in different ways.

On the one hand, Delecluse et al. (1994) and Latif and Grötzner (2000) assert that a Pacific El Niño in boreal winter is followed by an Atlantic Niño about 6 months later by causing anomalous easterly wind stress in the western equatorial Atlantic, deepening (shallowing) the thermocline in the west (east) Atlantic. This signal then propagates eastward and induces a Niño like event. According to Chang et al. (2006), the atmospheric response to El Niño is a warming in the equatorial Atlantic, but the dynamic ocean-atmosphere interaction in the Atlantic, known as Bjerknes feedback, counteracts the remote warming signal. This inconsistent relationship between the two Ocean basins is further investigated by Lübbecke and McPhaden (2012). Their study shows that a Pacific El Niño in boreal winter can be followed by an Atlantic Niña but also by an Atlantic Niño in the subsequent summer. They suggest that 
the northern tropical Atlantic (NTA, $\left.5^{\circ}-15^{\circ} \mathrm{N}, 30^{\circ} \mathrm{W}-10^{\circ} \mathrm{E}\right)$ thereby plays an important role.

On the other hand, the equatorial Atlantic is assumed to have an influence on the Pacific Ocean SSTs. Wang (2006) assume that there is a bilateral, positive feedback for climate variability of the tropical Pacific-Atlantic Oceans and the atmosphere system. Keenlyside and Latif (2007) identify an anti-correlation between the two oceans with a time lag of about 6 months. On this basis, Rodriguez-Fonseca et al. (2009), Losada et al. (2010) and Ding et al. (2012) further investigate the possible underlying mechanisms of the teleconnection from the Atlantic to the Pacific Ocean.

Previous studies are mainly based on observed and reanalysis data or on simulations from atmospheric general circulation models (AGCMs) or coupled general circulation models (GCMs) forced with observed SSTs, and they focus mostly on just one direction in the relationship between the Pacific and Atlantic equatorial modes. In contrast, this study analyzes, how state-of-the-art fully coupled GCMs and Earth system models (ESMs) without SST forcing simulate the complex mechanisms and interaction between the equatorial Pacific and Atlantic Oceans and especially considers both directions, Atlantic summer events lagging or leading Pacific boreal winter events. Thereby, the focus of this study is on the three currently most investigated teleconnections. The research into stand-alone fully coupled GCMs is important to both finding strengths and weaknesses of the current models and additionally allows us to make assumptions for the future development of global atmospheric states and also teleconnections.

The remainder of the paper is structured as follows: In Sect. 2, the applied data, models and methods are introduced. The results of the reanalysis and simulated interaction between the Atlantic and Pacific Oceans in both directions are shown in Sect. 3. Section 4 discusses the model results with respect to recent theories of teleconnections. Section 5 summarizes the major findings of this investigation.

\section{Data and methods}

\subsection{Data}

This study uses the monthly output of 15 fully coupled GCMs and ESMs that contribute to the fifth phase of the Coupled Model Intercomparison Project (CMIP5), see Table 1 . The first realizations of the historical simulations are applied, which impose changing conditions consistent with observations. Atmospheric composition, due to both anthropogenic and volcanic influences, solar forcing, aerosols and land use conditions are considered (Taylor et al. 2012). The historical simulations cover the period from 1861 to 2004.
To evaluate the model SST data, the Hadley Centre Sea Ice and Sea Surface Temperature data set (HadISST) version1.1 (Rayner et al. 2003) and the extended reconstruction sea surface temperature (ERSSTv3b, Smith et al. 2008) data are used. The twentieth century reanalysis (20CR) data (version 2, Compo et al. 2011) are used to evaluate the modelled atmospheric conditions during and following warm SST anomalies in the Pacific and Atlantic oceans. The period from 1871 to 1999 is used for the model evaluation.

Figure 1a, $\mathrm{b}$ show the annual mean climatologies of the observed and modelled SSTs, respectively. Figure 1c shows the mean model bias in ${ }^{\circ} \mathrm{C}$ of the CMIP5 model ensemble (model ensemble mean minus observed). Off the west coasts of Africa and South America, in the regions of the cold Benguela and Humboldt currents, the models overestimate the annual SSTs up to $6{ }^{\circ} \mathrm{C}$. Otherwise, the western Pacific basin and the Atlantic warm pool are underestimated by the GCMs (see also Liu et al. 2013) resulting in a diminished west-east SST gradient. However, the ability of the models to simulate the cold northward ocean currents differ a lot, illustrated by the standard deviations of the model biases in Fig. 1d.

The equatorial Atlantic variability and the biases of a CMIP5 ensemble are described in detail by Richter et al. (2014). They assume that the SST bias results from underestimated easterlies or even occurring westerlies at the equator in boreal spring. The thermocline in the southeast Atlantic is thus deepened and inhibits the upwelling of cold subsurface water.

\subsection{Methods}

To represent the SST variability of the Pacific Ocean, the Niño3 index $\left(150^{\circ} \mathrm{W}-90^{\circ} \mathrm{W}, 5^{\circ} \mathrm{N}-5^{\circ} \mathrm{S}\right)$ is used for both observed and model data. For the Atlantic Ocean, a recently developed SST index based on three sub-regions (black boxes in Fig. 1a) that represent the Benguela as well as the equatorial Atlantic Niños is applied for the observed HadISST data (ATLN1: $17^{\circ}-7^{\circ} \mathrm{S}$ and $8^{\circ}-15^{\circ} \mathrm{E}$, ATLN2: $10^{\circ}-3^{\circ} \mathrm{S}$ and $0^{\circ} \mathrm{W}-8^{\circ} \mathrm{E}$, ATLN3: $3^{\circ} \mathrm{S}-3^{\circ} \mathrm{N}$ and $15-0^{\circ} \mathrm{W}$, see Lutz et al. 2013). Note that this SST index is only applied to the observed data, but not to the model data.

For the CMIP5 models, the scores of all-season varimax rotated principal components (PCs)-representing the tropical southeastern Atlantic variability mode-are used as Atlantic SST indices to comply with the individual model characteristics. The additional rotation of the PCs is useful to get well defined and physically interpretable regions (Richman 1986). Thereby, the total amount of the explained variance (EV) is maintained, but the individual EVs are distributed more evenly onto all PCs. The individually selected PCs of the 15 investigated CMIP5 


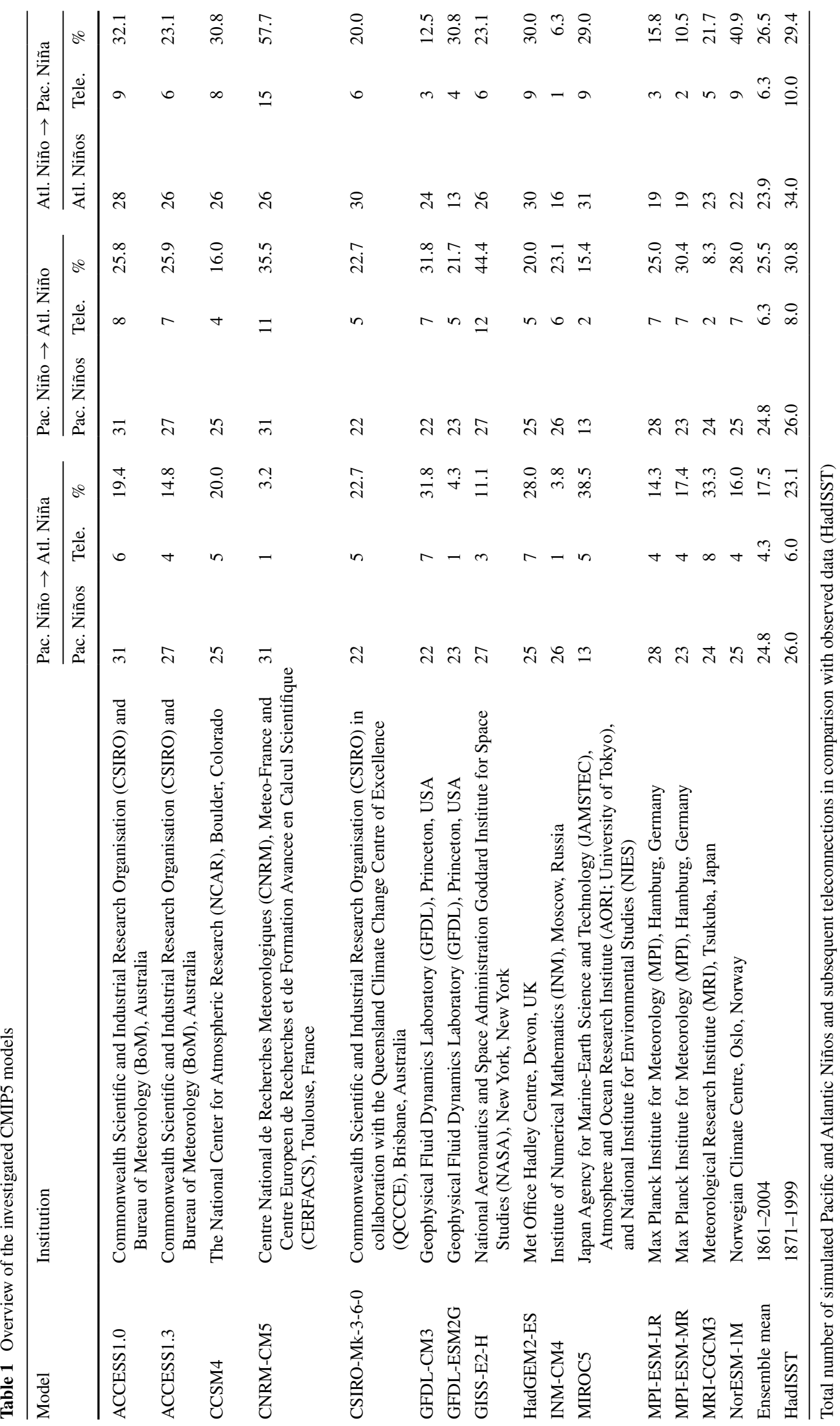



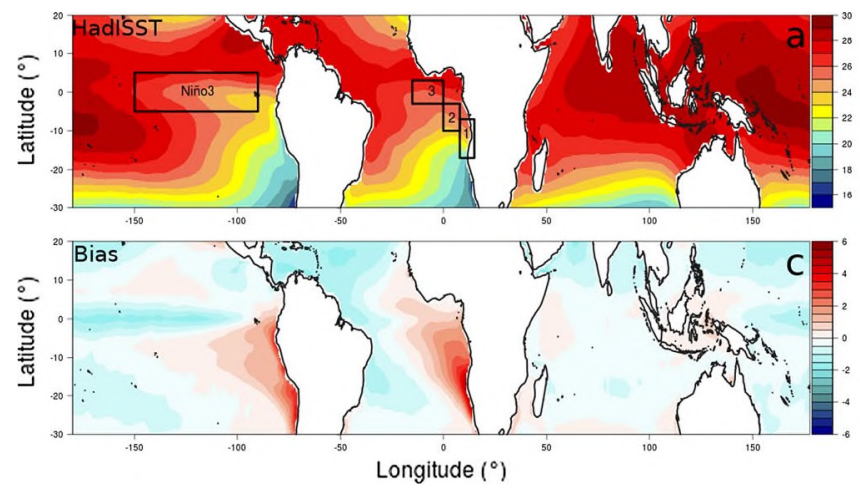

Fig. 1 a Annual mean observed SSTs (HadISST, 1871-1999) in ${ }^{\circ} \mathrm{C}$ with boxes for Nino3 and ATLN1-3 regions. b Annual mean modelled SSTs (CMIP5 ensemble mean, 1861-2004) in ${ }^{\circ} \mathrm{C}$. c Model SST

models which represent the Atlantic Niño mode, have EVs between 7 and $21 \%$. Similar to the results of Richter et al. (2014), only one-third of the ensemble describes the equatorial mode as the first PC. The Atlantic Niño modes of the remaining models are characterized by less dominant PCs. However, a comparison with the principal component analyses (PCA) of HadISST and ERSSTv3b data, which were only computed for evaluation purposes, shows that even the results for the observed SSTs include considerable differences. Thus, the year-round analysis of HadISST has the dominant pattern in the equatorial and coastal area with an EV of $21 \%$, whereas the Atlantic/Benguela Niño mode of ERSSTv3b is less dominant (PC 5) with an EV of $10 \%$. The spatial pattern of the first PC of ERSSTv3b (explaining an EV of $18 \%$ ) is located in the central South Atlantic at $25^{\circ} \mathrm{S}$, the second PC pattern (14\% EV) covers only the western central equatorial area and is thus also not suitable to represent both the equatorial and coastal parts of the Atlantic Niño phenomenon adequately (not shown here). Despite the fact that the Atlantic Niño mode is not represented by the first PC in all investigated CMIP5 models, the PC scores are better suited for the identification of Atlantic Niños in the model data than indices for a spatially fixed area that might not be able to catch the variability of the Atlantic Nino pattern in the model.

All data were de-trended using multiple 30 -year base periods that are updated every 5 years to calculate SST anomalies which are finally normalized over the whole study period. This procedure is based on the calculation of the Oceanic Niño Index (ONI) of the NOAA Climate Prediction Center (CPC) to remove the SST warming trend. The SST indices Niño3, ATLN1-3 and the input fields for the PCA are additionally filtered by a Gaussian high-pass filter to remove residual long term oscillations. Then, Pacific Niños/Niñas are defined by the exceeding of $1 \pm \mathrm{SD}$ for at least 3 consecutive months, and Atlantic

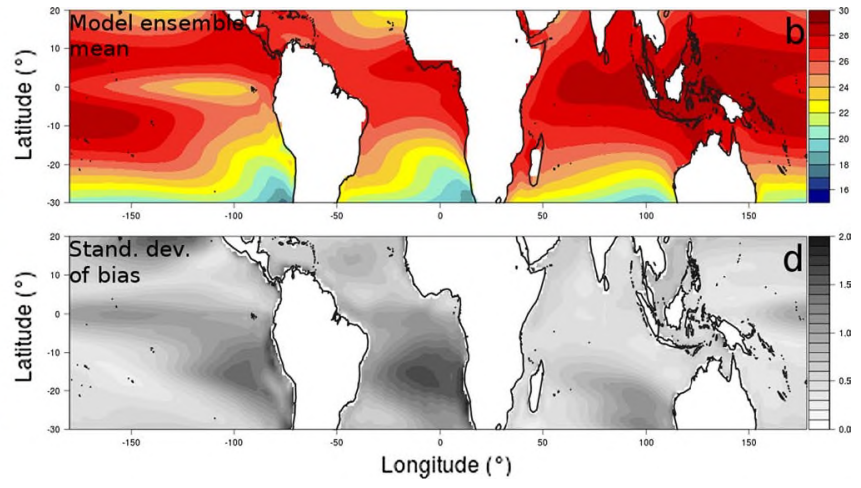

bias (model mean minus observed) in ${ }^{\circ} \mathrm{C}$. $\mathbf{d}$ Standard deviation of the model bias in ${ }^{\circ} \mathrm{C}$

Niños and Niñas are defined according to the method of Lutz et al. (2013). Their definition of cold and warm water events consists of three sub-types: Major event: all ATLN indices exceed one positive (negative) standard deviation for at least three consecutive months. Minor event: at least one index meets the warm (cold) event criterion; the other indices exceed an average of 0.5 standard deviations for at least one 3-month period. Warm (cold) episode: period consisting of multiple connected events, including at least one major event. SST anomalies between two events must not change the sign and the event-break must not last for more than 6 months. In our study, all resulting Niño events are considered in the HadISST data (major events, minor events and episodes).

Composite analyses are carried out for the reanalysis and model data with different time-lags and various variables (SST, precipitation, sea level pressure, wind, stream function, vertical air motion, velocity potential and divergent wind component at different levels between 1,000 and $200 \mathrm{hPa}$ ) to analyze the atmospheric and oceanic anomalous states during and after corresponding Niño events. To get a qualitative proof of the validity of the ensemble signals, only values with a model consensus of at least $70 \%$ are considered which means that e.g. 11 out of 15 models have to show the same anomaly signal. Additionally, the strength of the anomaly has to exceed the $0.2 *$ standard deviation of the modelled anomalies to avoid the inclusion of insignificant anomaly signals to the model ensemble mean. For the reanalysis composites, only statistically significant areas greater than $99 \%$ (Mann-Whitney-Wilcoxon test; see Bauer 1972 and Hollander and Wolfe 1973) are shown.

To investigate the three in current literature most analyzed remote responses to Atlantic and Pacific warm events, model data are selected with respect to the following assumptions: 

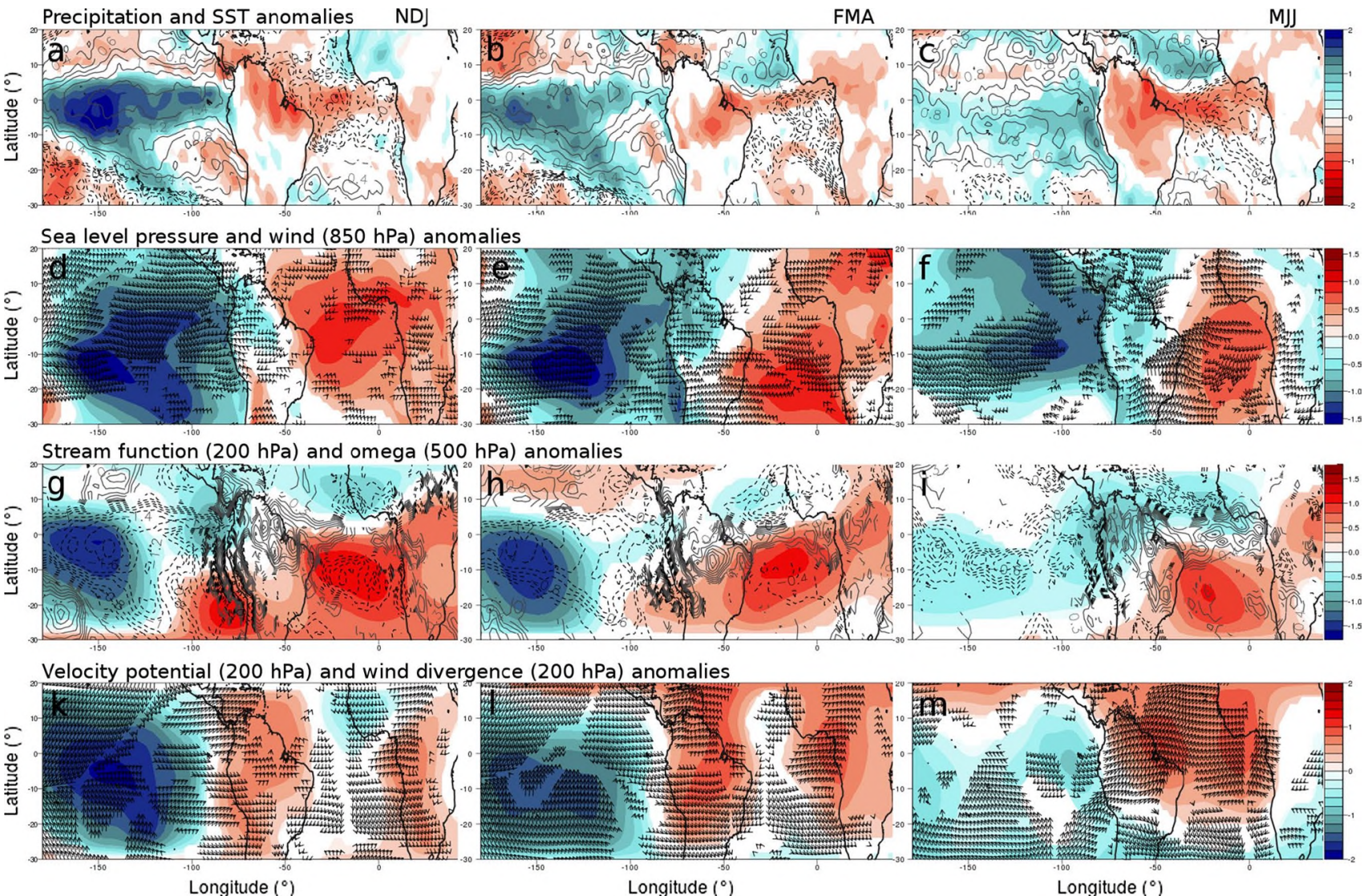

Fig. 2 Composites of the 20C reanalysis. Pacific El Niño in NDJ is followed by Atlantic Niña in MJJ. a-c Precipitation (shaded) and SST (contour) anomalies; d-f sea level pressure (shaded) and wind (850 hPa, arrows) anomalies; $\mathbf{g}-\mathbf{i}$ stream function $(200 \mathrm{hPa}$, shaded $)$ and omega (vertical velocity, $500 \mathrm{hPa}$, contour) anomalies; k-m velocity potential $(200 \mathrm{hPa}$, shaded $)$ and wind divergence $(200 \mathrm{hPa}$, arrows) anomalies. Values are normalized. Solid contours indicate positive, dashed contours indicate negative values. First column NDJ, second column FMA, third column MJJ. Only statistically significant areas greater than $99 \%$ (Mann-Whitney-Wilcoxon test) are shown
- A Pacific El Niño in the boreal winter season (NDJ, November to January) is followed by an Atlantic Niña in the subsequent boreal summer season (MJJ, May to July).

- A Pacific El Niño in boreal winter (NDJ) is followed by an Atlantic Niño in the subsequent boreal summer (MJJ).

- An Atlantic Niño in boreal summer (JJA, June to August) is followed by a Pacific La Niña in the subsequent boreal winter (DJF, December to February).

\section{Pacific and Atlantic teleconnections in the twentieth century reanalysis and the CMIP5 model ensemble}

\subsection{Pacific El Niño in NDJ is followed by Atlantic Niña in $\mathrm{MJJ}$}

In our analyses, the HadISST Nino3 index shows 26 Pacific El Niño events in the analyzed time period in NDJ from
1871 to 1999 , which is a mean frequency of occurrence of 5 years. 6 out of these 26 Pacific Niños (23\%) are followed by an Atlantic cold event about 6 months later.

In the CMIP5 model ensemble mean, the NDJ Pacific Niño develops on average every 5.8 years and $17.5 \%$ of all winter Pacific Niños from 1861 to 2004 are followed by an Atlantic Niña in the subsequent summer. Therefore, the analyzed models underestimate both, the occurrence of the Pacific El Niño and the teleconnection from a Pacific warm event to an Atlantic Niña (see Table 1).

Figure 2 shows the intensification of the Atlantic Niña through several time-lags on the basis of the 20CR anomaly composites. Only statistically significant areas greater than $99 \%$ are shown (evaluated with a MannWhitney-Wilcoxon test). In NDJ, the peak of the Pacific El Niño is fully developed (Fig. 2a, contours). Simultaneously, negative sea level pressure and upward vertical air motion anomalies (omega; negative values indicate upward motion) above the heat source occur (Fig. 2d, g, respectively). The equatorial easterlies are diminished 

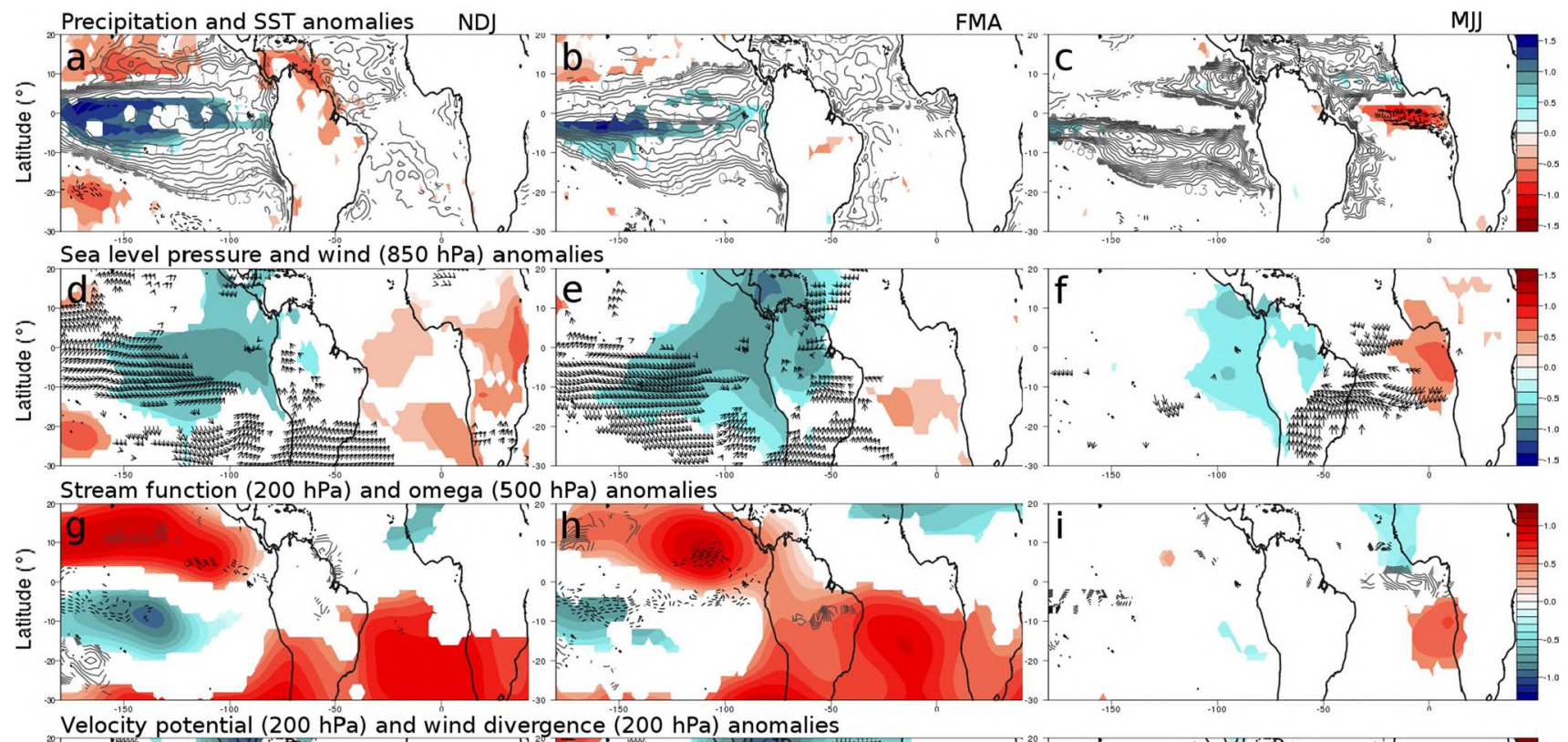

$500 \mathrm{hPa}$ ) anomalies
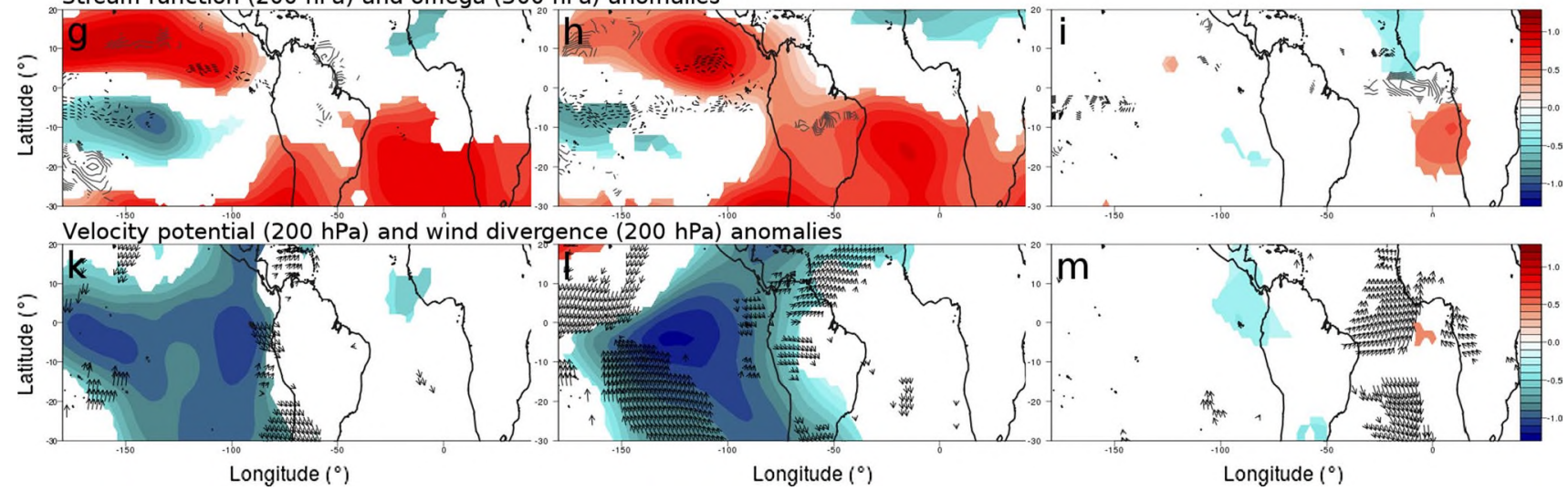

$200 \mathrm{hPa}$ ) anomalies
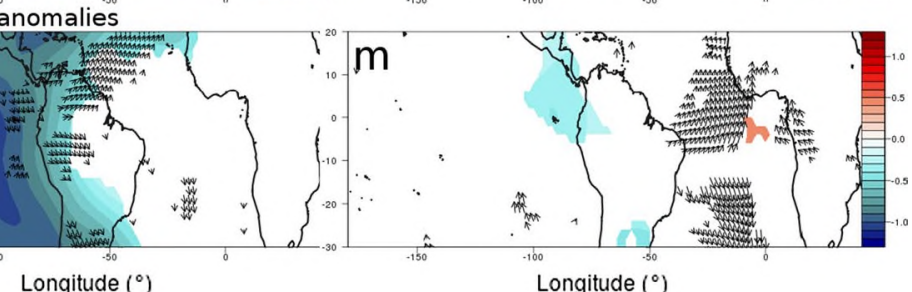

Fig. 3 Composites of the CMIP5 model ensemble mean. Pacific El Niño in NDJ is followed by Atlantic Niña in MJJ. a-c Precipitation (shaded) and SST (contour) anomalies; d-f sea level pressure (shaded) and wind (850 hPa, arrows) anomalies; $\mathbf{g}-\mathbf{i}$ stream function (200 hPa, shaded) and omega (vertical velocity, $500 \mathrm{hPa}$, con-

tour) anomalies; $\mathbf{k}-\mathbf{m}$ velocity potential $(200 \mathrm{hPa}$, shaded $)$ and wind divergence ( $200 \mathrm{hPa}$, arrows) anomalies. Values are normalized. Solid contours indicate positive, dashed contours indicate negative values. First column NDJ, second column FMA, third column MJJ. Values $>70 \%$ model consensus are shown

(Fig. 2d). In the upper troposphere, divergence arises (see negative anomalies of the velocity potential, Fig. 2k) and above the Pacific heat source forms a pair of anomalous anticyclones (Fig. 2h). Above the Atlantic Ocean, a pair of anomalous cyclonic movementcompleting a quadrupole structure of the upper-level stream function above the Pacific and Atlantic Oceansindicates the alteration of the Walker circulation of both oceans (Fig. 2g, h).

In boreal summer, the composites show strengthened negative SST anomalies at the equatorial and southeastern Atlantic Ocean (Fig. 2c, dashed lines) with associated positive sea level pressure anomalies (Fig. 2f), downward air motion anomalies (Fig. 2i) and lower-than-normal precipitation (Fig. 2c). The Atlantic cold water event amplifies the upper-level convergence (Fig. $2 \mathrm{~m}$ ) and the associated downward motion (Fig. 2i) at the eastern equatorial Atlantic.

The same composite analysis-but for the CMIP5 model ensemble-is shown in Fig. 3. For the composites, only values with a model consensus of at least $70 \%$ and distinct anomaly signals (at least $\pm 0.2 *$ standard deviation of anomalies) are considered. The model results are consistent with the teleconnection results of the reanalysis data in Fig. 2. However, the significant accordance between the models is concentrated on small areas for some variables. The anomalies of the sea level pressure in the Atlantic Ocean, for example, are only significant in a small area over the highest Atlantic SST anomalies (Fig. 3f). Around this region, the anomalies are either too small or they have divergent signs. As for the sea level pressure, the anomalies of the modelled vertical air movement are only significant where the reanalysis show the strongest signals (see Figs. $2 g-i, 3 g-i)$. The regions of upper-level convergences and especially the divergence above the Atlantic Ocean are also weakly defined by the models (Fig. 3k-m).

Figure 4 shows the significant shift of the downward branch of the Pacific Walker circulation to northeast Brazil and into the Atlantic Ocean in the CMIP5 data (Fig. 4a, b, see $0^{\circ}-50^{\circ} \mathrm{W}$ ). 

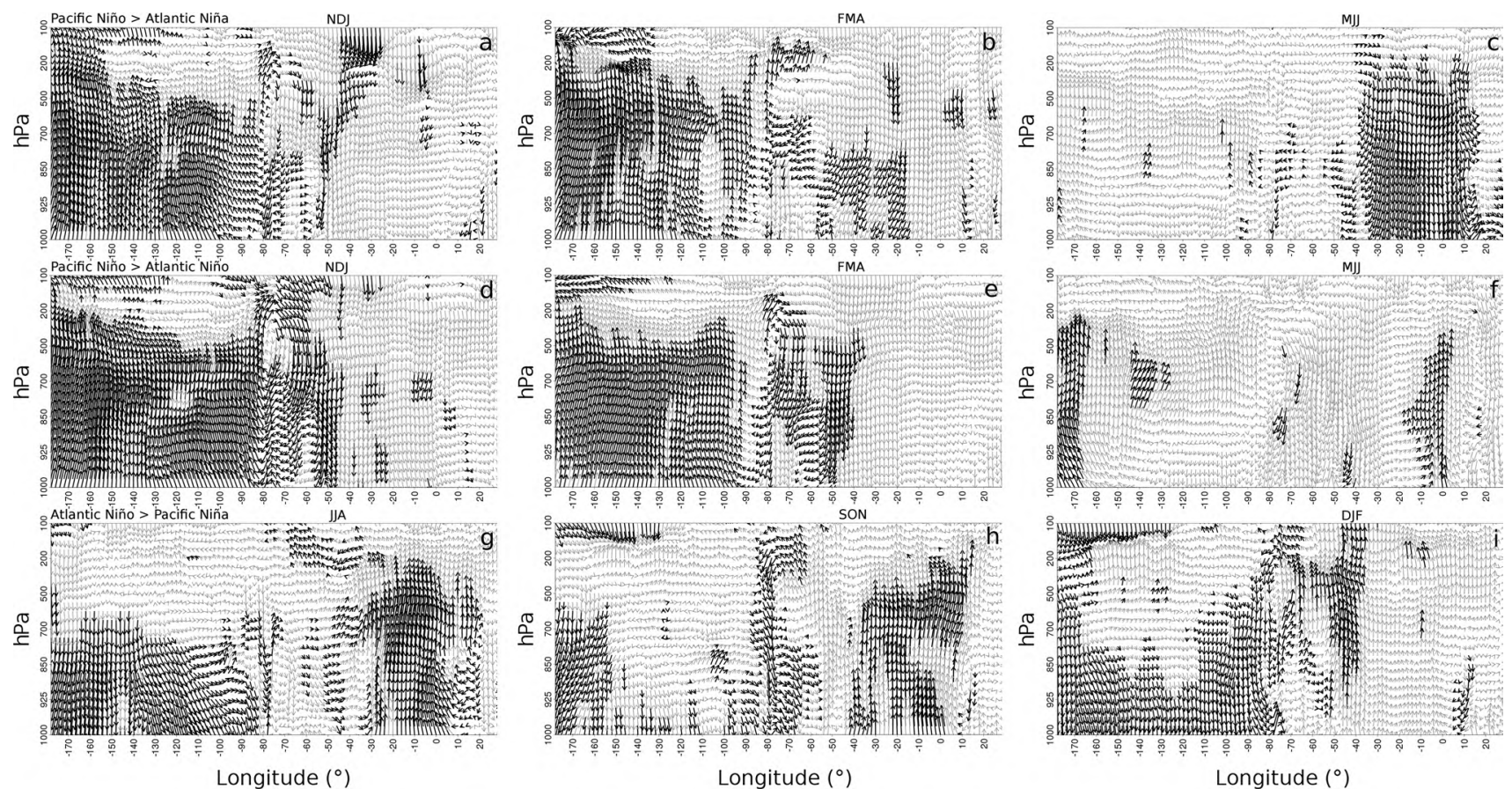

Fig. 4 Model ensemble mean composites of the Walker circulation anomalies at the equator $\left(2^{\circ} \mathrm{S}-2^{\circ} \mathrm{N}\right)$. Walker circulation anomalies computed from omega and the divergent wind component from seven height levels (1,000, 925, 850, 700, 500, 200, $100 \mathrm{hPa})$. a-c Pacific El
Niño in NDJ is followed by Atlantic Niña in MJJ. d-f Pacific El Niño in NDJ is followed by Atlantic Niño in MJJ. g-i Atlantic Niño in JJA is followed by Pacific La Niña in DJF. Bold arrows show a model consensus of at least $70 \%$

\subsection{Pacific El Niño in NDJ is followed by Atlantic Niño in $\mathrm{MJJ}$}

As in Fig. 2, the composites of the twentieth century reanalysis in Fig. 5 show a Pacific El Niño in boreal winter with the associated atmospheric anomalies (Fig. 5a, d, g, k). In the upper troposphere, a quadrupole structure of the stream function forms with a pair of anomalous anticyclonic movement (Fig. 5g) and divergence (velocity potential, Fig. 5k) above the tropical Pacific and a pair of anomalous cyclonic movement above the Atlantic Ocean (Fig. 5g), indicating an intensification of the Atlantic Walker cell. However, contrary to the first case, a warm SST anomaly appears in winter in the Southern Atlantic Ocean and strengthens throughout spring and summer (Fig. 5c). Typical atmospheric characteristics for an Atlantic Niño prevail like negative sea level pressure anomalies above the SST heat source (Fig. 5f), anomalous upward air motion and divergence anomalies in the upper troposphere (Fig. 5i, m, respectively) as well as anticyclonic upperlevel anomalies (Fig. 5h, i) that replace the initial cyclonic anomaly (Fig. $5 \mathrm{~g}$ ).

As for the 20CR data, the CMIP5 model ensemble mean shows the expected atmospheric response to a Pacific El Niño (Fig. 6). In contrast to the reanalysis, the models keep up the anomalous quadrupole structure until boreal spring (Fig. 6h). Although this atmospheric pattern should favor an Atlantic cold event, the Atlantic Niño amplifies in the summer months (Fig. 6c) like the observed SST data in Fig. 5c. The anomaly of the Walker circulation in Fig. 4 shows an eastward shift, although less intensively than for the first "cold case" (compare Fig. 4b, e).

The case that a Pacific El Niño in NDJ is followed by an Atlantic warm event in MJJ is more frequent than the cold response in both, the observed $(30.8 \%)$ and modelled $(25.5 \%)$ data. Again, the models underestimate the frequency of the teleconnection.

The applied CMIP5 models differ in their performances of the Pacific-Atlantic teleconnections. The analysis of the relative frequencies of teleconnections in Fig. 7a shows that there are models that prefer predominantly one kind of teleconnection: e.g. MRI-CGCM3 and MIROC5 simulate almost only Atlantic Niñas following Pacific El Niños, whereas GISS-E2-H and CNRM-CM5 predominantly simulate subsequent Atlantic warm events.

\subsection{Atlantic Niño in JJA is followed by Pacific La Niña in DJF}

The composites of the 20CR in Fig. 8 show that an Atlantic Niño in JJA (Fig. 8a) leads to anomalous upward air motion above the heat source and thus lower than normal 

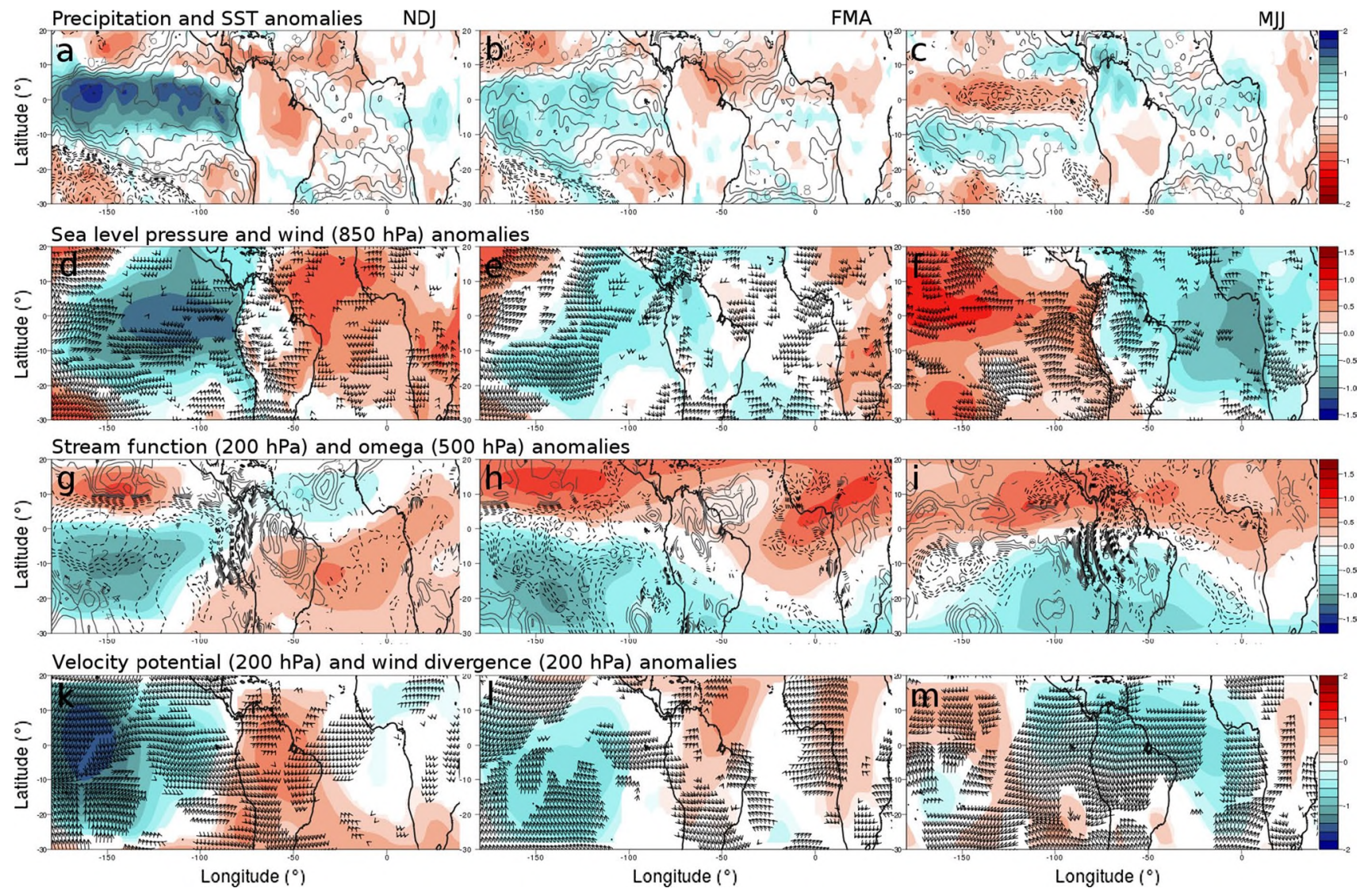

Fig. 5 Composites of the $20 \mathrm{C}$ reanalysis. Pacific El Niño in NDJ is followed by Atlantic Niño in MJJ. a-c Precipitation (shaded) and SST (contour) anomalies; d-f sea level pressure (shaded) and wind ( $850 \mathrm{hPa}$, arrows) anomalies; $\mathbf{g}-\mathbf{i}$ stream function $(200 \mathrm{hPa}$, shaded $)$ and omega (vertical velocity, $500 \mathrm{hPa}$, contour) anomalies; $\mathbf{k}-\mathbf{m}$ velocity potential $(200 \mathrm{hPa}$, shaded $)$ and wind divergence $(200 \mathrm{hPa}$, arrows) anomalies. Values are normalized. Solid contours indicate positive, dashed contours indicate negative values. First column NDJ, second column FMA, third column MJJ. Only statistically significant areas greater than $99 \%$ (Mann-Whitney-Wilcoxon test) are shown surface pressure (Fig. 8d, g, respectively). In the upper troposphere, anomalous divergence and a pair of anticyclonic anomalies above the Atlantic basin develop (Fig. 8h, $\mathrm{k}$, respectively). The velocity potential anomalies in Fig. 8k indicate an enhancement of the zonal pressure gradient between the Atlantic and the Pacific Oceans. Furthermore, an anomalous quadrupole structure of the stream function with convergent upper-level movement and a pair of anomalous cyclonic movement above the tropical Pacific strengthen in boreal fall (Fig. 8g-i).

In the subsequent winter season, negative SST anomalies in the tropical Pacific Ocean intensify (Fig. 8c) with related positive sea level pressure anomalies (Fig. 8f), descending vertical motion (Fig. 8i) and lower-than-normal precipitation (Fig. 8c) in the equatorial Pacific area.

The modelled atmospheric response (Fig. 9) to the Atlantic Niño in summer is quite well reproduced compared to the reanalysis data in Fig. 8. However, this kind of teleconnection is underestimated by the investigated CMIP5 models (26.5\%; HadISST: $29.4 \%$, see Table 1). The recurrence of the Atlantic Niños every 6 years, compared to 3.8 years in the observed data is also underestimated.

\section{Discussion of possible mechanisms of the reciprocal teleconnections}

In the scientific literature, two mechanisms are described that are able to transfer signals and anomalies from the Pacific ENSO system to the Atlantic region: First, the propagation of atmospheric wave train patterns via the extratropics, and second, the alteration and shift of the Walker and Hadley circulations.

Sutton et al. (2000) describe the North Atlantic remote response to ENSO by an atmospheric Rossby wave propagating through the extra-tropics, leading to alleviated northeastern trade winds in the Atlantic Ocean. Wang (2002) also states the decline of the trade winds in the northern Atlantic following a Pacific El Niño, however, initiated by the eastward shift of the Pacific Walker circulation with 


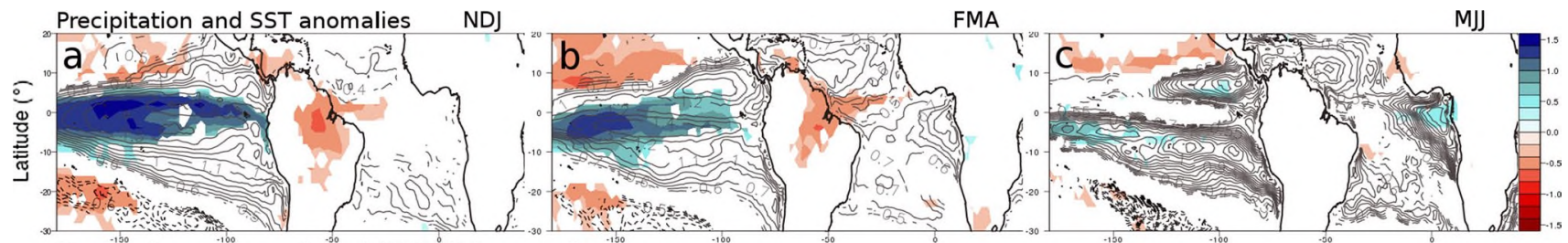

Sea level pressure and wind $(850 \mathrm{hPa})$ anomalies.
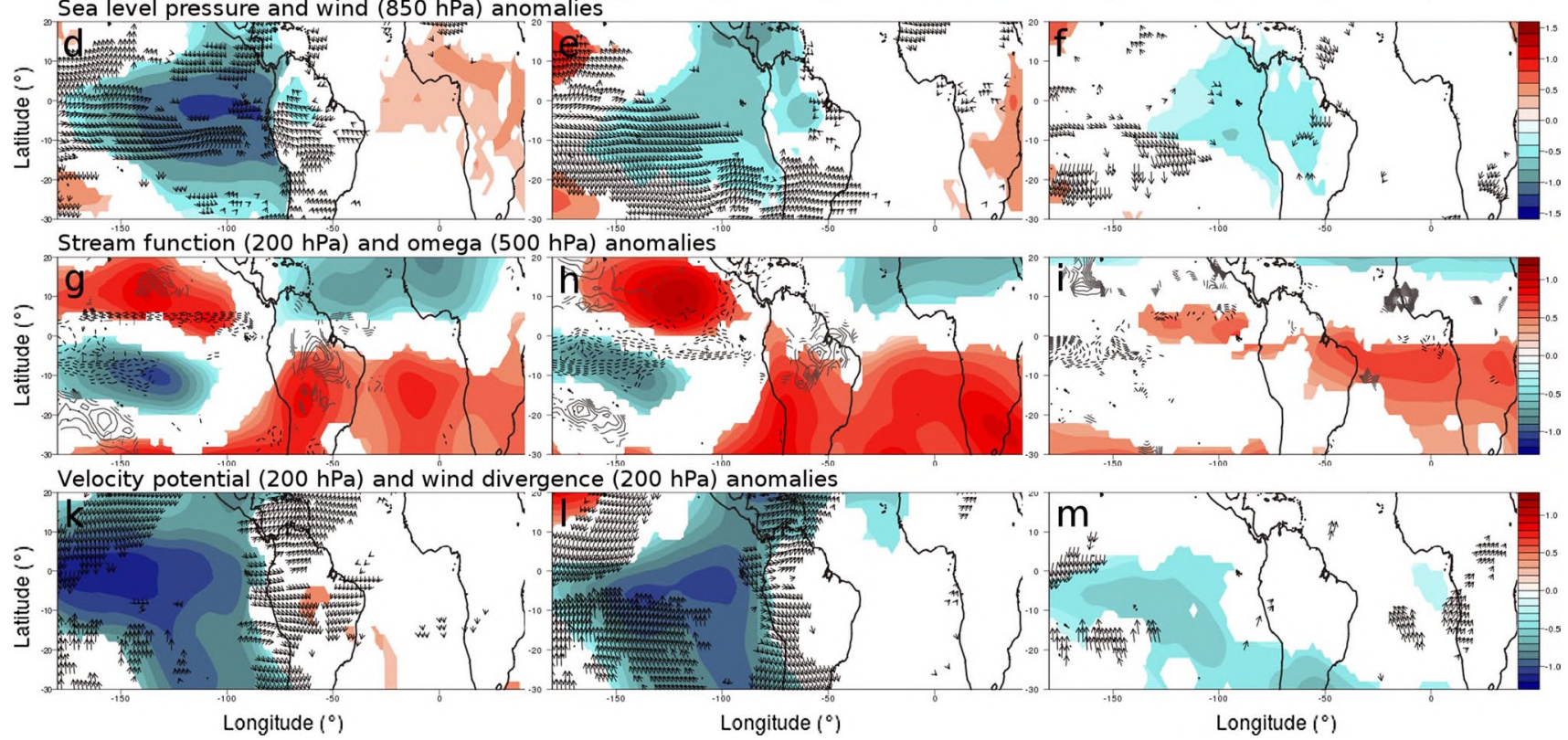

Fig. 6 Composites of the CMIP5 model ensemble mean. Pacific El Niño in NDJ is followed by Atlantic Niño in MJJ. a-c Precipitation (shaded) and SST (contour) anomalies; d-f sea level pressure (shaded) and wind (850 $\mathrm{hPa}$, arrows) anomalies; $\mathbf{g}-\mathbf{i}$ stream function (200 hPa, shaded) and omega (vertical velocity, $500 \mathrm{hPa}$, con-

a strong Walker cell in the Atlantic and a weaker associated Hadley cell. The resulting decrease of the trade winds entails diminished evaporation and an increase of the SSTs in the NTA.

According to Sutton et al. (2000), the southern Atlantic during an ENSO event is mainly dominated by the influence of the alteration of the Walker circulation. Thus, positive sea level anomalies associated with a negative Southern Oscillation Index over the western Pacific and Indian Ocean regions extend into the southern Atlantic. Analogous anomalies above the Atlantic Ocean can be found in the CMIP5 ensemble in Figs. 3d, e and 6d, e. Lübbecke and McPhaden (2012) propose that anomalous convection in the eastern Pacific alters the Walker circulation and therefore strengthens the southeast trades in the Atlantic Ocean. The modelled mechanism of the atmospheric anomaly propagation in our study is consistent with the findings of Lübbecke and McPhaden (2012) (see Fig. 4b for the altered Walker circulation and Fig. 3e for stronger easterlies in the Atlantic Ocean). The strengthened trade and easterly winds increase evaporation and can also induce a stronger tour) anomalies; $\mathbf{k}-\mathbf{m}$ velocity potential (200 $\mathrm{hPa}$, shaded $)$ and wind divergence ( $200 \mathrm{hPa}$, arrows) anomalies. Values are normalized. Solid contours indicate positive, dashed contours indicate negative values. First column NDJ, second column FMA, third column MJJ. Values $>70 \%$ model consensus are shown

upwelling of cold water off the coast of Africa. The result is a cooling of the surface water in the south-eastern and equatorial Atlantic (Bhaskaran and Mullan 2003; Seager et al. 2003).

Lübbecke and McPhaden (2012) investigated possible atmospheric and oceanic mechanisms for the case that a Pacific Niño in winter is followed by a tropical Atlantic warm event in the subsequent summer season. The reason for the occurrence of these warm water events in the equatorial South Atlantic is seen in the preceding anomalous strong warming of the NTA. This warming induces a strong meridional SST gradient, leading to negative wind stress curl in the western-central Atlantic in boreal spring and a resulting westward downwelling oceanic Rossby wave. This Rossby wave gets reflected and moves to the eastern Atlantic as a downwelling Kelvin wave. The warm water layer of the Kelvin wave counteracts the initial cooling in the eastern Atlantic and can lead to an Atlantic Niño. Richter et al. (2012) also attribute great importance to the influence of the NTA on the equatorial and southern Atlantic temperature anomalies, however, they state another 


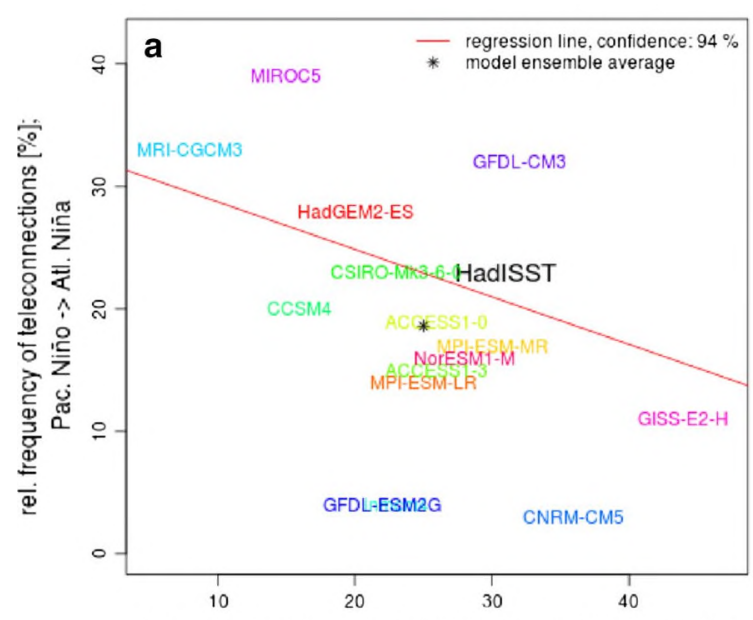

rel. frequency of teleconnections [\%]; Pac. Niño -> Atl. Niño

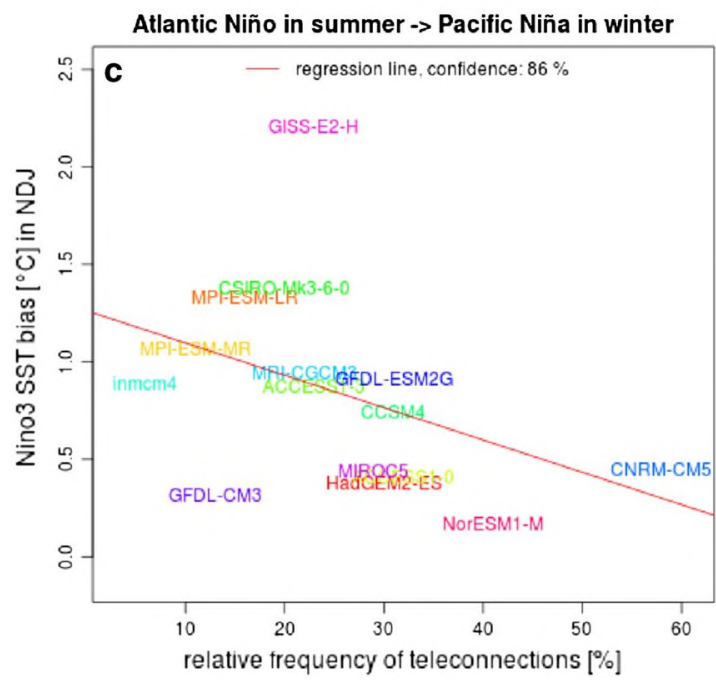

Fig. 7 Scatterplots of teleconnection characteristics and SST biases of the CMIP5 model ensemble. a Relation of the relative frequency of the two different teleconnections from the Pacific to the Atlantic Ocean. b Relation between the relative frequency of the teleconnection Pacific Nino $\rightarrow$ Atlantic Nino and the JJA SST bias in the

underlying mechanism. In this case, surface wind forcing north of the equator causes subsurface warm water anomalies which are then directly advected towards and off the equator in meridional directions.

Following the theory of Lübbecke and McPhaden (2012), the modelled SSTs of our CMIP5 ensemble in the NTA must be warmer in the Atlantic "warm response" than in the Atlantic Niña "scenario". The CMIP5 ensemble means of both cases show, with a high inter-model consensus, a warming of the NTA in boreal spring (Figs. 3b, 6b, contour lines). But no significant difference of the magnitude of NTA warming between the "warm-response" and the "cold-response" cases is observed. Furthermore, no explicit wind or wind stress anomaly difference required
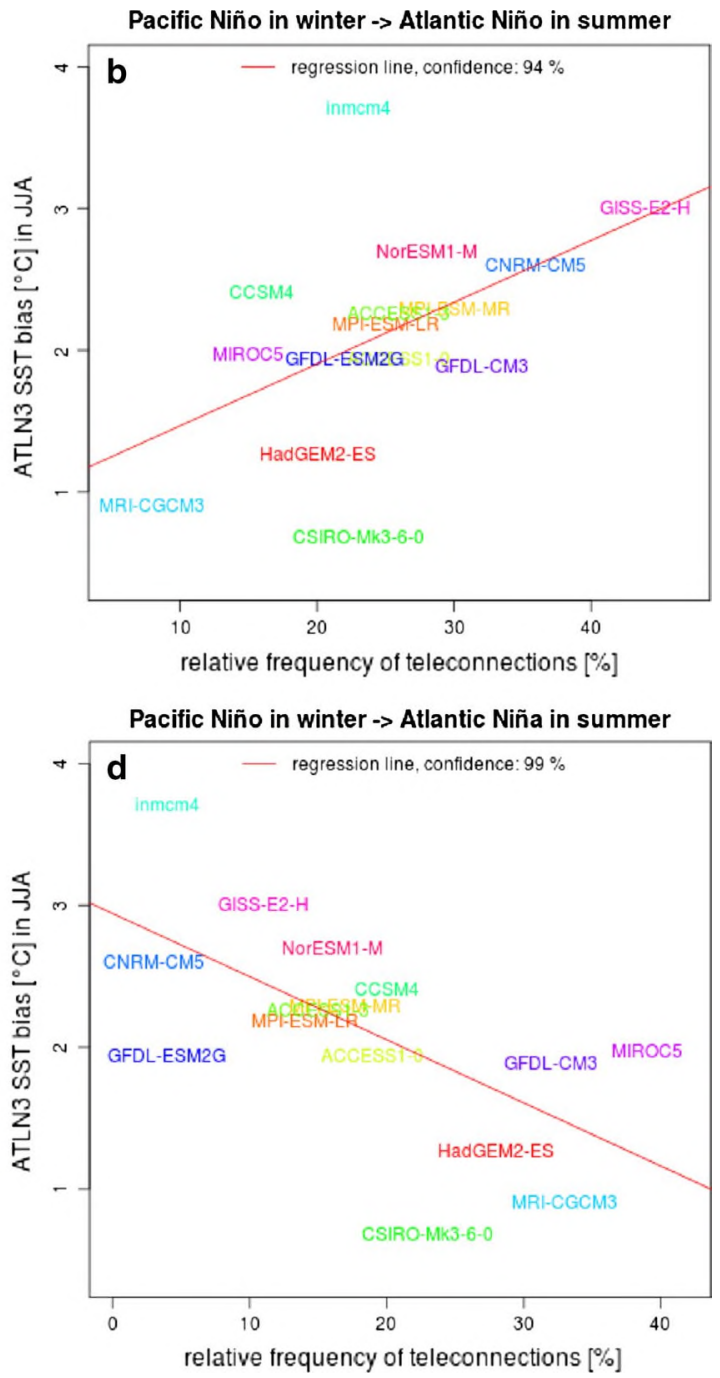

ATLN3 region. $\mathbf{c}$ Relation between the relative frequency of the teleconnection Atlantic Nino $\rightarrow$ Pacific Nina and the NDJ SST bias in the Nino3 region. d Relation between the relative frequency of the teleconnection Pacific Nino $\rightarrow$ Atlantic Nina and the JJA SST bias in the ATLN3 region

for the support of Richter's theory is found in the analyzed model output (Figs. 3e, f, 6e, f). But what alternative explanation may exist for the development of an Atlantic Niño preceded by a Pacific El Niño in the CMIP5 model output?

We suggest that, at least in our analyzed model ensemble, a distinct simultaneous warming in both oceans impedes the development of an Atlantic cold event. Figure $6 \mathrm{~b}$ shows that with a high model consensus, a warming of the southeast Atlantic exists immediately after the mature phase of the Pacific El Niño in contrast to the "cold response" in Fig. 3b. Additionally, the eastward shift of the Walker circulation is less pronounced and almost dissolves during late boreal spring (Fig. 4e). The weaker Walker anomaly and the persisting positive SST anomaly 

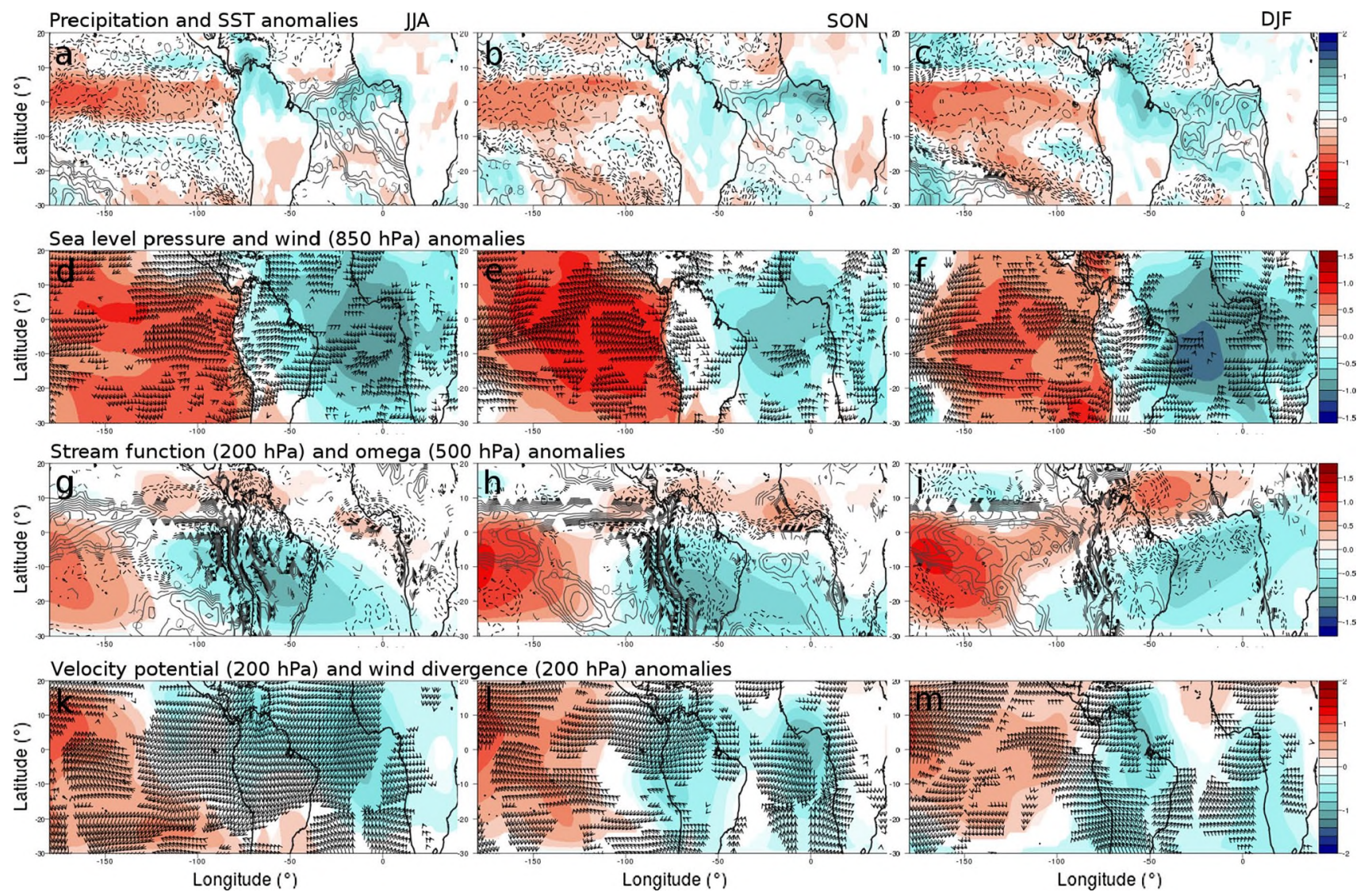

Fig. 8 Composites of the 20C reanalysis. Atlantic Niño in JJA is followed by Pacific La Niña in DJF. a-c Precipitation (shaded) and SST (contour) anomalies; $\mathbf{d}-\mathbf{f}$ sea level pressure (shaded) and wind $(850 \mathrm{hPa}$, arrows) anomalies; $\mathbf{g}-\mathbf{i}$ stream function $(200 \mathrm{hPa}$, shaded $)$ and omega (vertical velocity, $500 \mathrm{hPa}$, contour) anomalies; $\mathbf{k}-\mathbf{m}$ velocity potential (200 hPa, shaded) and wind divergence (200 hPa, arrows) anomalies. Values are normalized. Solid contours indicate positive, dashed contours indicate negative values. First column JJA, second column SON, third column DJF. Only statistically significant areas greater than $99 \%$ (Mann-Whitney-Wilcoxon test) are shown in the Atlantic Ocean impair the development of a positive sea level pressure deviation in the South-Atlantic (compare Figs. 3e, 6e). As a consequence, the southeast trade winds and the equatorial easterlies are not strengthened, as the impact of the existent warm water anomaly in the SouthAtlantic seems to exceed the remote ENSO influence (compare Figs. 3e, f, 6e, f). The findings of Sutton et al. (2000) support this theory as they describe that with a mid-basin warm SST anomaly, the trade winds to the west are anomalously weak and impede evaporation and upwelling of cold water to the east. Chang et al. (2006) also supposed that warm water anomalies in the equatorial Atlantic Ocean impede the development of easterly wind anomalies in the western Atlantic and thus the formation of an Atlantic cold event.

Moreover, the model SST bias affects the relative frequency of Pacific-Atlantic teleconnections and seems to have an influence on the precise transfer of anomalies from the atmosphere into the ocean. Thereby, the SST bias of the lagging ocean is more important than the SST bias of the leading ocean for a completed teleconnection. Figure $7 \mathrm{~b}-\mathrm{d}$ illustrates the relations between the three investigated types of teleconnections and the particular SST bias in the lagging ocean. Figure $7 \mathrm{~b}$ shows that a large SST bias in the ATLN3 region in boreal summer favors the case of an Atlantic warm event following a winter Pacific El Niño. A smaller bias, in contrast, reduces the relative frequency of subsequent warm Atlantic events. An even stronger relationship between the relative number of teleconnections and the SST bias exist when an Atlantic Niña follows a Pacific El Niño (Fig. 7d). Here, a strong Atlantic SST bias impedes the development of Atlantic cold events, whereas a weaker bias enables the occurrence of more such events. This suggests that even if the atmospheric signal generated by the Pacific El Niño reaches the Atlantic sector, it might be too weak to alter the already sparse and biased upwelling of cold subsurface water off the African coast.

The third case that is discussed here, is the remote influence of the equatorial Atlantic on the Pacific Ocean. The possible underlying mechanism is studied by e.g. 

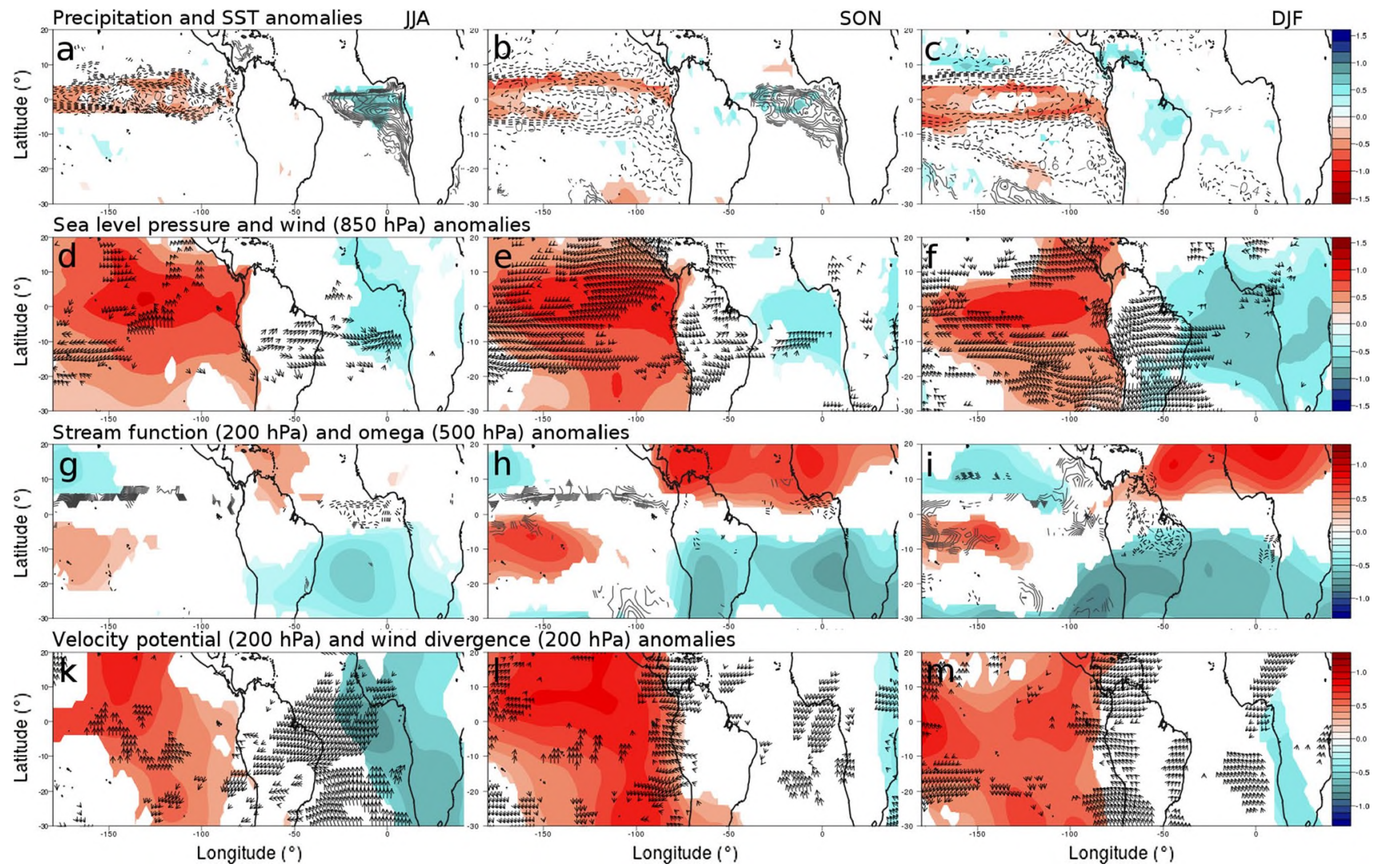

Fig. 9 Composites of the CMIP5 model ensemble mean. Atlantic Niño in JJA is followed by Pacific La Niña in DJF. a-c Precipitation (shaded) and SST (contour) anomalies; d-f sea level pressure (shaded) and wind (850 hPa, arrows) anomalies; g-i) stream function (200 hPa, shaded) and omega (vertical velocity, $500 \mathrm{hPa}$, con-

Rodriguez-Fonseca et al. (2009), Losada et al. (2010) and Ding et al. (2012). They propose an alteration of the Walker circulation cells around the equator by an Atlantic Niño during boreal summer.

The model results are in agreement with their findings. The anomalous quadrupole structure of the stream function (convergent upper-level movement and a pair of anomalous cyclonic movement above the tropical Pacific in Fig. 9g-i) and the anomalous downward movement at the eastern Pacific (Fig. 4h, i) indicate a reinforcement of the Pacific Walker circulation. The associated mid-basin trade winds and the equatorial easterlies in the Pacific Ocean (see Fig. 9e, f) are strengthened, thus inducing the shallowing of the thermocline in the eastern Pacific. This favors the amplification of a developing Pacific La Niña (Fig. 9c).

As for the teleconnections from the Pacific to the Atlantic, Fig. 7c shows that the SST bias in the Pacific Ocean influences the effectiveness of the interaction from the Atlantic to the Pacific Ocean. Models that have a large SST bias in the Nino3 region in NDJ feature a smaller relative frequency of successful teleconnections resulting in tour) anomalies; $\mathbf{k}-\mathbf{m}$ velocity potential (200 $\mathrm{hPa}$, shaded) and wind divergence (200 hPa, arrows) anomalies. Values are normalized. Solid contours indicate positive, dashed contours indicate negative values. First column JJA, second column SON, third column DJF. Values $>70 \%$ model consensus are shown

a Pacific La Niña than models that show a weaker Pacific SST bias.

\section{Conclusion}

Our study summarizes the present research about the teleconnections between the equatorial Atlantic and Pacific Oceans and tests 15 state-of-the-art fully coupled GCMs and ESMs from CMIP5 without prescribed SSTs for their ability to represent the atmospheric and oceanic conditions during and after Atlantic and Pacific Niño and Niña events and the particular propagation of anomaly signals. In contrast to many other studies, the teleconnections in both directions-from the Pacific to the Atlantic and from the Atlantic to the Pacific - are considered.

However, not all models simulate each of the assumed teleconnections with the correct frequency. This is likely due to strong SST biases in the upwelling regions off the coast of western Africa and also in the Pacific Ocean. These biases impair the accurate signal propagation from 
the atmosphere to the ocean and thus disrupt the impact of the initial remote teleconnection pattern.

Therefore, an improvement of the simulation of the cold Benguela and the Humboldt currents and maybe also the amendment of the interaction between atmosphere and ocean in these models is urgently required. Guilyardi et al. (2004) detected that biased wind fields, e.g. stronger than normal trade winds, have an influence on the coupling between the atmosphere and the ocean models in GCMs and thus can impact the sensitivity of the atmosphere to SST changes.

This study shows that most of the models are able to transfer anomaly patterns to the adjacent ocean and thus amplify the development of a warm or cold SST event there. However, it also shows that a large ensemble size of fully-coupled models without prescribed SSTs is necessary to ensure the quality and validity of the teleconnection results.

Acknowledgments Financial support was provided by the DFG (German Research Foundation) under contract JA 831/9-1.

\section{References}

Bauer DF (1972) Constructing confidence sets using rank statistics. J Am Stat Assoc 67:687-690

Bhaskaran B, Mullan A (2003) El Nino-related variations in the southern Pacific atmospheric circulation: model versus observations. Clim Dyn 20:229-239

Carton JA, Huang B (1994) Warm events in the tropical Atlantic. J Phys Oceanogr 24:888-903

Chang P, Fang Y, Saravanan R, Ji L, Seidel H (2006) The cause of the fragile relationship between the Pacific El Niño and the Atlantic Niño. Nature 443:324-328

Compo GP, Whitaker JS, Sardeshmukh PD, Matsui N, Allan RJ, Yin $\mathrm{X}$, Gleason BE, Vose RS, Rutledge G, Bessemoulin P, Brönnimann S, Brunet M, Crouthamel RI, Grant AN, Groisman PY, Jones PD, Kruk M, Kruger AC, Marshall GJ, Maugeri M, Mok HY, Nordli $\varnothing$, Ross TF, Trigo RM, Wang XL, Woodruff SD, Worley SJ (2011) The twentieth century reanalysis project. Q J R Meteorol Soc 137:1-28. doi:10.1002/qj.776

Delecluse P, Servain J, Levy C, Arpe K, Bengtsson L (1994) On the connection between the 1984 Atlantic warm event and the 19821983 ENSO. Tellus A 46:448-464

Ding H, Keenlyside NS, Latif M (2012) Impact of the equatorial Atlantic on the El Niño southern oscillation. Clim Dyn 38:1965-1972

Florenchie P, Reason C, Lutjeharms J, Rouault M, Roy C, Masson S (2004) Evolution of interannual warm and c old events in the southeast Atlantic Ocean. J Clim 17:2318-2334

Guilyardi E, Gualdi S, Slingo J, Navarra A, Delecluse P, Cole J, Madec G, Roberts M, Latif M, Terray L (2004) Representing El
Niño in coupled ocean-atmosphere GCMs: the dominant role of the atmospheric component. J Clim 17:4623-4629

Hollander M, Wolfe D (1973) Nonparametric statistical methods. Wiley, New York

Hong CC, Li T, Chen YC (2010) Asymmetry of the Indian Ocean Basinwide SST anomalies: roles of ENSO and IOD. J Clim 23:3563-3576

Keenlyside NS, Latif M (2007) Understanding equatorial Atlantic interannual variability. J Clim 20:131-142

Klein SA, Soden BJ, Lau NC (1999) Remote sea surface temperature variations during ENSO: evidence for a tropical atmospheric bridge. J Clim 12:917-932

Latif M, Grötzner A (2000) The equatorial Atlantic oscillation and its response to ENSO. Clim Dyn 16:213-218

Liu H, Wang C, Lee SK, Enfield D (2013) Atlantic warm pool variability in the CMIP5 simulations. J Clim 26:5315-5336

Losada T, Rodriguez-Fonseca B, Polo I, Janicot S, Gervois S, Chauvin F, Ruti P (2010) Tropical response to the Atlantic Equatorial mode: AGCM multimodel approach. Clim Dyn 35:45-52

Lübbecke JF, McPhaden MJ (2012) On the Inconsistent Relationship between Pacific and Atlantic Niños. J Clim 25:4294-4303

Lutz K, Rathmann J, Jacobeit J (2013) Classification of warm and cold water events in the eastern tropical Atlantic Ocean. Atmos Sci Lett 14:102-106

Rayner NA, Parker DE, Horton EB, Folland CK, Alexander LV, Rowell DP, Kent EC, Kaplan A (2003) Global analyses of sea surface temperature, sea ice, and night marine air temperature since the late nineteenth century. J Geophys Res 108(D14):4407. doi: 10.1029/2002JD002670

Richman M (1986) Rotation of principal components. Int J Climatol 6:293-335

Richter I, Behera SK, Masumoto Y, Taguchi B, Sasaki H, Yamagata $\mathrm{T}$ (2012) Multiple causes of interannual sea surface temperature variability in the equatorial Atlantic Ocean. Nat Geosci 6:43-47

Richter I, Xie SP, Behera S, Doi T, Masumoto Y (2014) Equatorial Atlantic variability and its relation to mean state biases in CMIP5. Clim Dyn 42:171-188

Rodriguez-Fonseca B, Polo I, Garcia-Serrano J, Losada T, Mohino E, Mechoso CR, Kucharski F (2009) Are Atlantic Niños enhancing Pacific ENSO events in recent decades? Geophys Res Lett 36:L20705. doi:10.1029/2009GL040048

Seager R, Harnik N, Kushnir Y, Robinson W, Miller J (2003) Mechanisms of hemispherically symmetric climate variability. J Clim 16:2960-2978

Smith TM, Reynolds RW, Peterson TC, Lawrimore J (2008) Improvements to NOAA's historical merged land-ocean surface temperature analysis (1880-2006). J Clim 21:2283-2296

Sutton R, Jewson S, Rowell D (2000) The elements of climate variability in the tropical Atlantic region. J Clim 13:3261-3284

Taylor KE, Stouffer RJ, Meehl GA (2012) An overview of CMIP5 and the experiment design. Bull Am Meteorol Soc 93:485-498

Wang C (2002) Atlantic climate variability and its associated atmospheric circulation cells. J Clim 15:1516-1536

Wang C (2006) An overlooked feature of tropical climate: interPacific-Atlantic variability. Geophys Res Lett 33:L12702. doi:10. 1029/2006GL026324

Webster PJ, Palmer TN (1997) The past and the future of El Niño. Nature 390:562-564

Zebiak SE (1993) Air-sea interaction in the equatorial Atlantic region. J Clim 6:1567-1586 